\title{
COVID-19 Contact Tracing: Ghana's Efforts in the Application of Geospatial Technology in Minimizing the Impact of the Pandemic
}

\author{
Emmanuel Yeboah, Isaac Sarfo, Clement Kwang, Michael Batame, Foster Kofi Addai, \\ George Darko, Solomon Obiri Yeboah Amankwah, Jones Nketiah, \\ Emmanuella Aboagye Appea, and Collins Oduro
}

\section{ABSTRACT}

COVID-19 has presented unusual challenges for individuals, governments and societies across the globe. Several non-medical and nonpharmaceutical interventions have demonstrated to be critical in addressing the resultant impacts. One notable tool among these interventions is the application of technology in identifying infected persons or individuals coming into contact with those infected. Policy think-tanks have invested in geospatial technology and information systems to help resolve contact tracing inefficiencies to curtail the fast spread of the disease. This study highlights the extent of the application of geospatial technology in COVID-19 contact tracing in Ghana. Here, it was demonstrated that majority of young adults that form the greater part of Ghana's population have access to digital devices which serve as primary catalysts in facilitating effective and efficient contact tracing. Case count of the pandemic continues to surge sharply from one month to the other since the first recorded case on March 12, 2020. A huge number of cases were recorded in the southern part of the country, as against cases recorded in the north. Mobility patterns depicted the migration of more people from regions with a high number of case count to regions with lower counts. We recommend a holistic and proactive approach to the use of smart mobile devices and applications in enhancing contact tracing. Privacy and data protection laws must be prioritized and supported by effective legislative and policy frameworks that serve as the legal basis for the management of personal information.

Keywords: COVID-19, contact tracing, Ghana, Mobile GIS.
Published Online: November 26, 2021 ISSN: 2736-660X

DOI: $10.24018 /$ ejdevelop.2021.1.4.47

\section{E. Yeboah}

Department of Geography \& Resource Development, University of Ghana, Legon, Ghana.

(e-mail: eyeboah037@st.ug.edu.gh)

I. Sarfo*

Research Institute for History of Science and Technology, Nanjing University of Information Science and Technology, Jiangsu, China.

(e-mail: 20195129001@nuist.edu.cn)

C. Kwang

Department of Geography \& Resource Development, University of Ghana, Legon, Ghana.

(e-mail: ckwang@ug.edu.gh)

M. Batame

Department of Natural Resources Management, University of Twente, Enschede, the Netherlands.

(e-mail:

michaelbatame8@gmail.com)

F. K. Addai

Department of Geography \& Resource Development, University of Ghana, Legon, Ghana.

(e-mail: fkaddai001@st.ug.edu.gh)

G. Darko

Department of Environment and Biotechnology, Nha Trang University, Vietnam.

(e-mail:

durowaavivian45@gmail.com)

S. O. Y. Amankwah

School of Geographic Sciences, Nanjing University of Information Science and Technology, Jiangsu, China.

(e-mail: 20195111003@nuist.edu.cn)

J. Nketiah

Department of Geography \& Resource Development, University of Ghana, Legon, Ghana.

(e-mail: papajones440@yahoo.com)

E. A. Appea

Department of Geography \& Resource Development, University of Ghana, Legon, Ghana.

(e-mail: appeaella@gmail.com)

C. Oduro

Research Institute for History of Science and Technology, Nanjing University of Information Science and Technology, Jiangsu, China.

(e-mail: 20205129001@nuist.edu.cn)

* Corresponding Author 


\section{INTRODUCTION}

Most economies across the globe have experienced unexpected and undesirable shocks, emanating from the Corona Virus Disease, 2019 (COVID-19), believed to have originated from a laboratory in the city of Wuhan, China in December 2019 (Shereen et al., 2020; Wu et al., 2020). The World Health Organization (WHO) on 11 March 2020, pronounced the Coronavirus Disease 2019 (COVID-19) as a global pandemic. According to Sun et al. (2020), COVID-19 quickly affected thousands of people in China, spreading pervasively among other countries like Germany, Italy, United States, Republic of Korea, Japan, Viet Nam, Thailand and Singapore. However, the juxtaposition of situations surrounding MERS-CoV (Middle East Respiratory Syndrome-related coronavirus) of 2012/2014, SARS-CoV-2 and SARS-CoV of 2002/2003 even indicates that the COVID-19 spreads exceptionally faster than was anticipated although coronaviruses are not new (Gao et al., 2020). The veracity of its spread and devastating impact to mankind caused the WHO to declare the COVID-19 a Public Health Emergency of International Concern (PHEIC) on the $30^{\text {th }}$ January, 2020 (WHO, 2020). African governments are taking the maximum control measures in spite of the lower infections rates compared to other parts of the world. With the poor testing capacity and generally underdeveloped healthcare systems in Africa, governments have taken the precautionary measures (Sibiri et al., 2020).

As of October 8, 2021, the Ghana Health Service (GHS) recorded about 128, 209 (1158 deaths) cases of COVID-19 in Ghana, making it one of the most impacted countries in Africa. Government officials are not inputting directives or instituting a nationwide lockdown. Instead, their primary COVID-19 response approach uses '3T's', namely tracing, testing, and treatment. Although Ghana's cases keep soaring, the country's response has attracted global commendation by being placed among the best countries with prudent responses according to WHO. They further recommended some of Ghana's techniques, particularly, its pool testing method measures (Sibiri et al., 2020). A rapid and effective implementation of evidence-based containment measures is crucial given the magnitude, duration, and complexity of the epidemic in Ghana. Contact tracing is one of the interventions that have been used to effectively control disease outbreaks on the African continent (WHO, 2014). Traditionally, contact tracing has been done by human tracers, who engage infected patients in relation to recent contacts, with follow-up and quarantine measures (Sapiezynski et al., 2020). Kenu et al. (2020) disclosed that surveillance and contact tracing were strategies employed to deliver medical care to infected people. This process was conducted within 1-2 km radii away from the location of the infected patients. For instance, during the lockdown period in Ghana, a relational geodatabase on mobile GIS application was built by using ArcGIS Collector to map all the contact information and location of infected people within a specified area (Afagbedzi et al., 2021). This mobile GIS relational geodatabase was an important application that facilitated the real-time surveillance and COVID-19 contact tracing in Ghana (Afagbedzi et al., 2021). Ghana was the first West African country to have used drones, with in-built geospatial technologies to combat the pandemic (Sarfo \& Karuppannan, 2020). GIS and Remote Sensing applications have been used by the Ghana Statistical Service (GSS) and Ghana Health Service (GHS) in the fight against the pandemic by displaying information such as confirmed, active, recovered and death cases on dashboards (Sarfo \& Karuppannan, 2020). The GIS platforms, including ArcGIS online makes it possible to visualize and analyze spatial distribution of mapped COVID19 contact tracing cases (Owusu et al., 2021). Mobile based Geographic Information Systems (GIS) application for contact tracing promises to solve these limitations (Soroush et al., 2020). If it works as intended, nations or key proponents would not have to rely on faulty memories. The application could "remember" the people we do not even know, as long as both the entire population or group involved have compatible mobile devices with access to internet. The study therefore seeks to unravel the potential challenges of COVID-19 contact tracing in Ghana, coupled with the extent to which geospatial technology has been applied or could be applied to reduce some of the challenges which constitute, but are not limited to fear, stigma, abuse of privacy and community misperceptions regarding COVID-19. Furthermore, the study sought to address factors that may influence the spread of the virus.

\section{Description OF THE STUdy AREA}

Ghana is a developing country within sub-Saharan Africa. Ghana forms part of the 22 countries that make up West Africa. It lies on the latitude $7.9465^{\circ} \mathrm{N}$ and longitude $1.0232^{\circ} \mathrm{W}$ (Fig. 1). Ghana has a total land area of $238,535 \mathrm{~km}^{2}$. Accra is the capital city of Ghana and holds the seat of Government. The country had 10 administrative regions until 2017 where six new regions were created. These regions constitute Greater Accra, Ashanti, Western, Western North, Central, Upper East, Upper West, North East, Savannah, Northern, Volta, Oti, Bono, Bono East, Ahafo and Eastern. Ghana is characterized by two main seasons, the rainy and dry seasons, which makes it a tropical climate. The rainy season in Ghana starts from March to September as the main rainy season. Between November and February, the trade winds blow across the areas in the northeast and the conditions are very dry (Agyapong et al., 2014). Ghana has six agro-ecological zones, namely Sudan savannah (Bawku), tropical rainforest (Western part), Coastal savannah, Forest transitional zone, Deciduous Forest zone and Guinea savannah. Ghana is characterized by different mountain ranges. Typical minerals mined are manganese, gold and 
diamond. According to the World Bank's (2019) projections, Ghana has a population of about 30 million. $50.9 \%$ of Ghana's population are males whereas $49.1 \%$ are females. The populaces in Ghana have different cultural backgrounds. The largest percentage of the population is engaged in mining, fishing, agriculture, and service. Agriculture contributes a lot to the country's growth and development through exports and domestic consumption. In terms of infrastructural development, Ghana has embarked on several projects aimed at enhancing or improving capital expenditure or livelihoods, respectively.

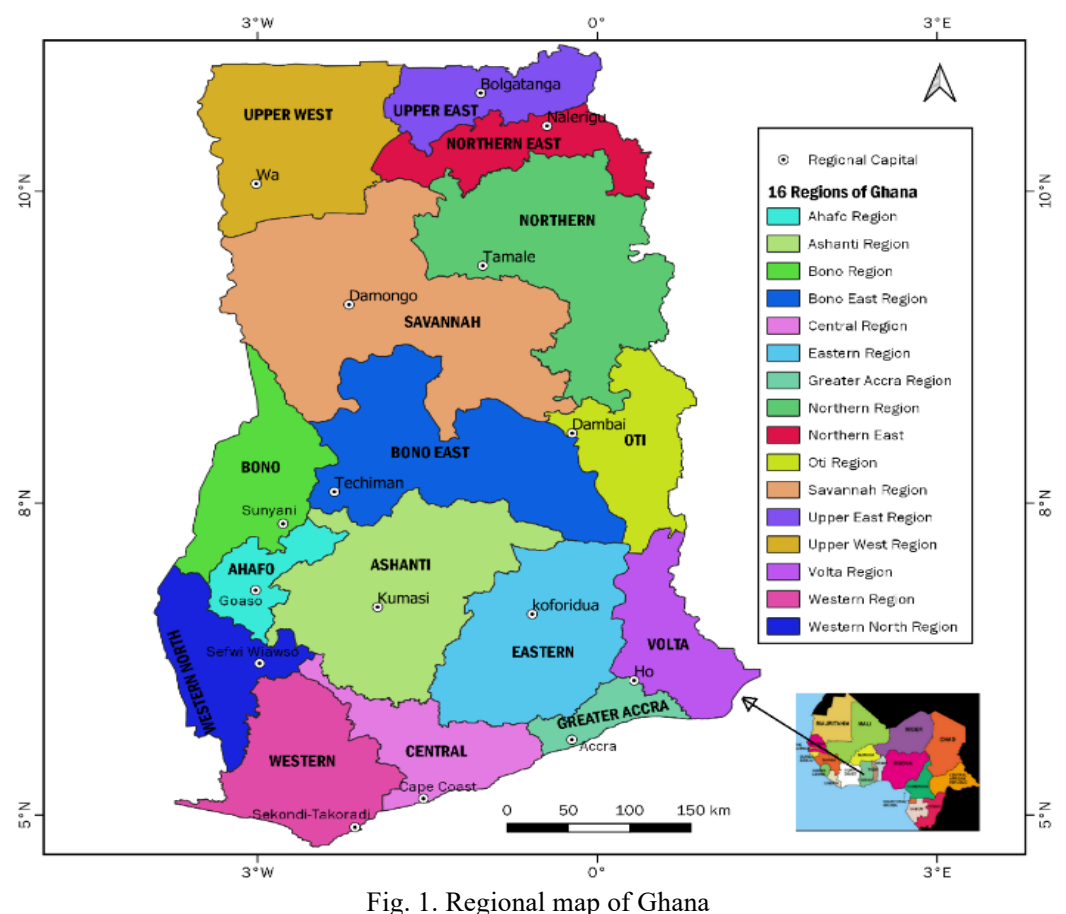

III. MATERIALS AND METHODS

\section{A. Data Collection}

Data used for this study are COVID-19 and population data of Ghana. Population data and population statistics were synthesized according to the sixteen administrative regions Ghana Statistical Service (GSS) as of 2019c. Ghana's regional outlines in shape file were acquired from the RS/GIS Lab of the Department of Geography and Resource Development at the University of Ghana. COVID-19 data was added to the regional boundaries (in Universal Traverse Mercator Zone $30 \mathrm{~N}$ ) using the join table algorithm. COVID19 data presented and used for this study was derived from several sources, including WHO dashboards, Ghana Statistical Service, Ghana Health Service, and Vodafone Ghana as a means to establish the consistencies in data used. The practical goal of many studies in social sciences is to solve a specific problem or suggest alternatives (Steinberg \& Steinberg, 2006). According to Elwood \& Cope (2009), GIS is mainly related to statistical and quantitative spatial analysis. Muijs (2010), as well as Leung \& Shek (2018) employed this means to gather numerical data to explain a particular phenomenon. The targeted population was people residing in Ghana. The survey instrument used in this project was a structured questionnaire. A sample size of 1500 people were selected at random using the accidental technique. The questionnaire was designed using google forms and administered to capture people's views on GIS or Global Positioning System (GPS) application in COVID-19 contact tracing. Respondents provided answers regarding knowledge about the existence of GIS/GPS features on their smart mobile phones, along with their awareness of the existence, usability and accessibility of the GH COVID-19 Mobile Tracker App (owned by the Government of Ghana) which was launched to aid the COVID-19 contact tracing process.

\section{B. Indicators and Measurement Criteria}

Finding the eigenvectors $\left(\mathrm{V}_{\mathrm{p}}\right)$ of each criterion for each item is how you develop and prioritize a matrix, as represented by the equation:

$$
\mathrm{V}_{\mathrm{p}}=n \sqrt{\mathrm{W} 1_{\mathrm{x}}+\mathrm{W}_{\mathrm{n}}}
$$

where $\mathrm{n}$ is the number of parameters to compare, and $\mathrm{W}_{\mathrm{n}}$ denotes the major parameters to compare. The criteria weight $\left(\mathrm{C}_{\mathrm{W}}\right)$ is calculated using the following formula: 


$$
C_{w}=\frac{V_{p}}{V_{p} 1+\cdots+V_{p n}}
$$

All of a matrix's parameters' criteria weights $\left(\mathrm{C}_{\mathrm{w}}\right)$ must add up to 1 . The matrix is also normalized by dividing each element by the sum of the columns, and the priority vector $[\mathrm{C}]$ is found by averaging each line. Furthermore, by multiplying each column of the matrix by the priority vector that corresponds to it, the overall priority [D] is determined. Each global priority is also divided by the priority vector that corresponds to it to find the rational priority [E]. (3) is used to calculate the value of the maximum eigenvalue $(\lambda \max )$.

$$
\lambda \max =\frac{|E|}{n}
$$

The consistency index $(\mathrm{CI})$ is calculated by:

$$
\mathrm{CI}=(\lambda \max -\mathrm{n}) /(\mathrm{n}-1)
$$

(5) is used to compute the consistency ratio (CR). The possibility that the croak is performed at random is explained by the ratio of coherence. In many cases, the responses are incomprehensible. In most cases, AHP does not demand that judgments be consistent or transitive. It is implied by Saaty's, (1980) definition of consistency ratio that an element is consistent when its consistency ratio is $\leq 0.1$.

$$
\mathrm{CR}=\frac{\mathrm{CI}}{\mathrm{RI}}
$$

\section{AHP Challenges and Preventive Elements}

The elements outlined in this study constitute the challenges in using geospatial technology in contact tracing, coupled with preventive measures in Ghana. In assigning weights, we calculated the eigenvector $\left(\mathrm{V}_{\mathrm{p}}\right)$ and weight coefficient $\left(\mathrm{C}_{\mathrm{w}}\right)$ to show their impacts in relation to consistency levels. Random index (RI) values are given in Table I.

\begin{tabular}{cc} 
TABLE I: THE SAME-DIMENSION RANDOM INDEX MATRIX \\
\hline No. of Criteria & RI \\
\hline 2 & 0.00 \\
3 & 0.58 \\
4 & 0.90 \\
5 & 1.12 \\
6 & 1.24 \\
7 & 1.32 \\
8 & 1.41 \\
9 & 1.45 \\
10 & 1.49 \\
11 & 1.51 \\
\hline
\end{tabular}

\section{Research Models and Techniques}

The interview, focus group discussion, and questionnaire results were examined by AHP methods to organize the elements posing challenges towards the use of geospatial technology in contact tracing, among other preventive measures into a hierarchical structure, thereby assigning weights and calculating their levels of consistency.

E. AHP Model Process: Challenges in Applying Geospatial Technology in Contract Tracing and Implementing Preventive Measures

An AHP constructs a problem according to hierarchical structures, then, put forwards alternatives according to a user's judgement Saaty, (1980). This is dependent on paired comparisons. Evaluated criteria and their weights are then, decided according to their importance. The analysis was done in six steps, developed by Saaty (1980), and cited in a study conducted by Darko et al. (2021):

- Dissecting a complex, unstructured situation into its constituent elements;

- Creating the AHP hierarchy;

- Creating a paired comparison matrix by imposing judgements;

- Assigning values to subjective judgements and determining the respective weights of each criterion;

- Combine judgments to determine the most important variables;

- Verify that assessments and judgments are consistent.

Calculation of consistency ratio is one of the integral qualities of AHP (Saaty, 1980). If consistency ratio is $\leq 0.1$, then the indicated elements of the matrix is considered as an acceptable consistency. In this study, there are three levels that projects the AHP approach: 


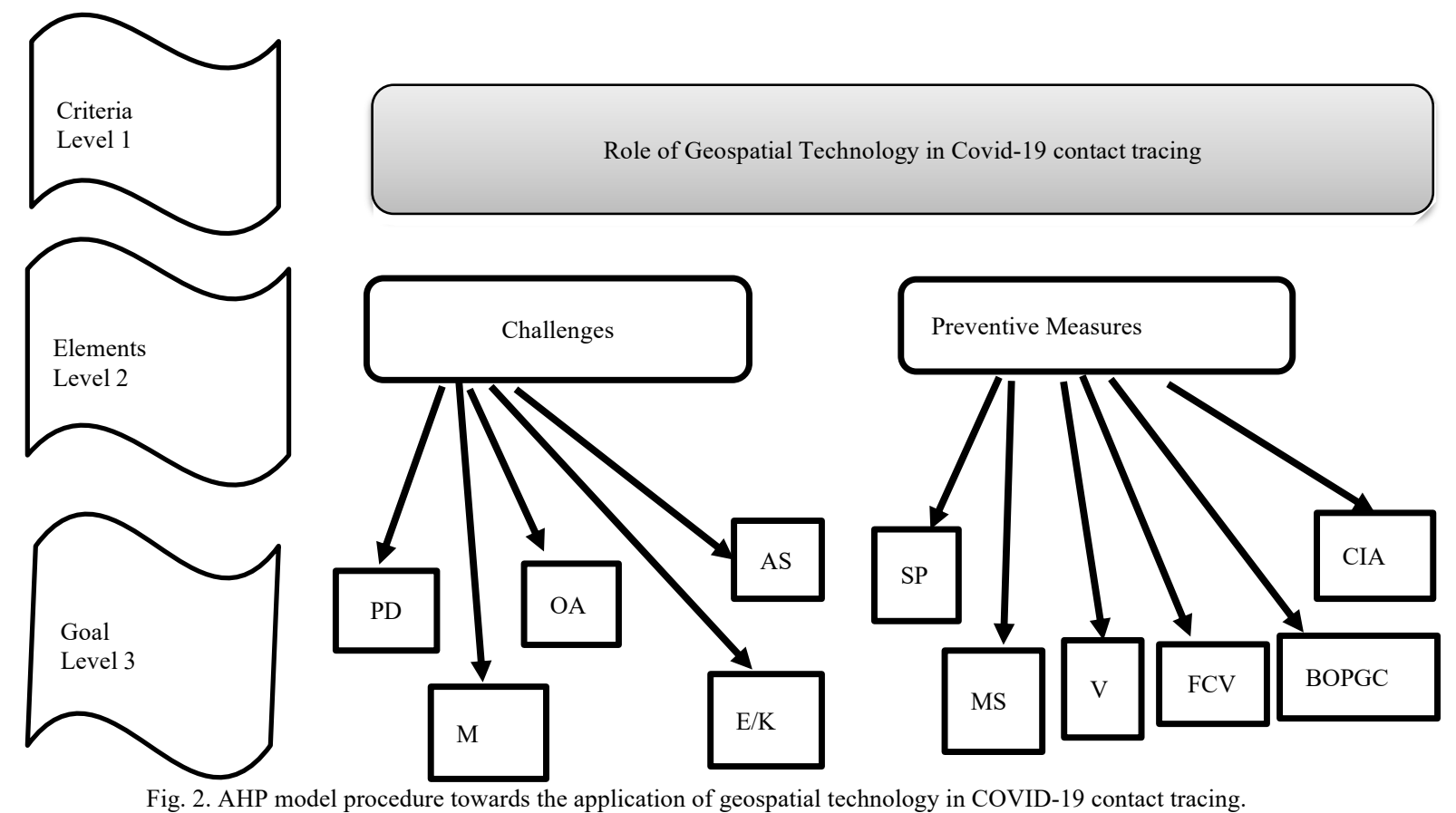

Challenges - population density (PD), overcrowded areas (OA), age structure (AS), educational status/knowledge (E/K) and mobility (M).

Preventive Measures - safety protocols (SP), vaccination (V), ban on public gatherings and ceremonies (BOPGC), media sensitization (MS), Fear of contracting the virus (FCV), community and individual aid (CIA).

\section{F. Principles for Selecting Each Weight Factor (AHP)}

The principle is to develop a matrix that expresses the hierarchical arrangement of relative values of challenging factors to the goals of geospatial technology in contact tracing and adopted preventive measures. Participants made choices based on the degree of importance of the key parameters linked to the goals of geospatial technology in contact tracing and weights assigned to each parameter based on Saaty's scale. Practically, if for instance, population density/safety protocols labelled (Element A) is more important than age structure/vaccines labelled (Element B), then A is rated 3, whereas B becomes less important than $A$, and $B$ is valued at $1 / 3$. The challenges and preventive measures elements are compared using the pairwise technique, and their respective weights are computed (eigenvector). The element structure indicates which elements should be prioritized.

\section{G. Hierarchic Elaboration}

The AHP is divided into three levels: level 1 is linked to the study's goal, level 2 captures criteria analysis of challenging and preventative factors, and level 3 highlights the elements that make up challenges and preventive measures (see Fig. 2) (Darko et al., 2021; Danumah et al., 2016; Nejad et al., 2015; Pourghasemi et al., 2014; Chakraborty \& Joshi, 2014; Saaty 1980).

TABLE II: SAATY SCALE FOR COMPARING VARIOUS ELEMENTS

\begin{tabular}{|c|c|c|}
\hline Scale & Judgement of Preference & Description \\
\hline 1 & Equally important & Two factors contribute the same to the objective \\
\hline 3 & Moderately important & Experience and judgement, slightly favor one over the other \\
\hline 5 & Important & Experience and judgement, strongly important favor one over the other \\
\hline 7 & Very strongly important & Experience and judgement, deemed strongly important which prioritizes one of the other \\
\hline 9 & Extremely important & The evidence favoring one over the other is of the highest possible validity \\
\hline $2,4,6,8$ & Intermediate preference & When compromise is needed between two adjacent scales \\
\hline
\end{tabular}

\section{RESULTS AND DISCUSSIONS}

\section{A. Socio-Demographic of Respondents}

In the context of effective contact tracing of COVID-19 cases, the socio-demographics of the respondents may be necessary in the contact tracing process, which enables health experts to identify hotspot zones and monitor the COVID-19 cases. In this study, the results showed most of the respondents during the data collection were males (64\%), while the remaining (36\%) were females.

Age of respondents in this study ranged between $22-29$ years (74.8\%) while $22.4 \%$ were distributed within the age range of 30-39 years, with $40-49$ years constituting $2.8 \%$. 
European Journal of Development Studies www.ej-develop.org

Per educational status, most of the respondents had attained Tertiary education (91.6\%), while 5.8\% had Senior High School level of education. A few of the respondents had attained (2.6\%) Junior High School level of education.

TABLE III: SOCIO-DEMOGRAPHIC CHARACTERISTICS OF RESPONDENTS

\begin{tabular}{ccc}
\hline \multicolumn{1}{c}{ Variable } & Frequency (n) & Percentage (\%) \\
\hline \hline Gender & & 64 \\
Male & 960 & 36 \\
Female & 540 & \\
Age of Respondents & & 74.8 \\
22-29 years & 1122 & 22.4 \\
30-39 years & 336 & 2.8 \\
40-49 years & 42 & \\
Highest level of Education & & 2.6 \\
Junior High School (JHS) & 39 & 5.8 \\
Senior High School (SHS) & 87 & 91.6 \\
Tertiary & 1374 & \\
\hline \hline
\end{tabular}

Table IV presents information about respondents' knowledge, usability, and accessibility of the GIS/GPS feature on their mobile devices. From the study, $72 \%$ had some knowledge about the GIS/GPS features on their smartphones; $28 \%$ had no knowledge about the usage of GIS/GPS technologies $41.8 \%$ were not aware of the COVID-19 Mobile app tracker. Additionally, 83.4\% were of the view that they have not accessed the COVID-19 Mobile app tracker on their smartphones.

From the study, most of the respondents $(67.4 \%)$ reported that they are likely to report probable symptoms of COVID-19 cases when faced with using the Mobile tracker app, while about $30.6 \%$ of the respondents were cited using alternative approaches in reporting cases.

TABLE IV: RESPONDENTS' KNOWLEDGE, USABILITY AND ACCESSIBILITY TO GH COVID-19 MOBILE TRACKER APP

\begin{tabular}{|c|c|c|}
\hline Variables & Frequency $(\mathrm{n})$ & Percentages $(\%)$ \\
\hline \multicolumn{3}{|c|}{ Knowledge of GIS/GPS feature on the mobile device } \\
\hline Yes & 1080 & 72 \\
\hline No & 420 & 28 \\
\hline \multicolumn{3}{|c|}{ Awareness about the GH COVID-19 mobile app tracker } \\
\hline Yes & 873 & 58.2 \\
\hline No & 627 & 41.8 \\
\hline \multicolumn{3}{|c|}{$\begin{array}{l}\text { Have you ever accessed the GH COVID-19 Mobile App } \\
\text { Tracker on your Smart Phone? }\end{array}$} \\
\hline Yes & 249 & 16.6 \\
\hline No & 1251 & 83.4 \\
\hline \multicolumn{3}{|c|}{ Report probable symptoms of COVID-19 using the GH } \\
\hline \multicolumn{3}{|c|}{ COVID-19 Mobile Tracker App } \\
\hline Yes & 1041 & 69.4 \\
\hline No & 459 & 30.6 \\
\hline
\end{tabular}

\section{B. Spatial Distribution of COVID-19 Cases in Ghana}

COVID-19 cases were distributed across the 16 administrative regions of Ghana. However, there were variations in cases recorded by each region. Analyzing the cases according to the various belts in Ghana; the northern zone constituting Upper East, Upper West, North East, Savannah, and the Northern region had relatively smaller cases, as compared to the other belts. In the northern belt, Northern region recorded the highest COVID-19 cases followed by Upper East, Upper West, North East and Savannah regions. North East region had the least percentage of recovered cases, representing 88.1\% (Table V). On the other hand, the middle belt regions included Ahafo, Bono, Bono East, Ashanti, Eastern and Oti of which Ashanti region recorded the highest number of active cases.

The coastal regions (southern belt) comprise of Western, Western North, Central, Volta and the Greater Accra. Greater Accra was the region with the highest number of cases followed by Western, Central, Volta and Western North. In terms of the active cases across the country, the Greater Accra region has recorded the highest number of cases, followed by the Ashanti region in the central belt, and finally, the Western region in the southern belt. 


\begin{tabular}{cccc}
\hline \hline Regions & Cases & \% Recovered & $\begin{array}{c}\text { Active } \\
\text { Cases }\end{array}$ \\
\hline \hline Ahafo & 1.054 & 94.5 & 23 \\
Ashanti & 20.602 & 98.4 & 457 \\
Bono & 2.089 & 95.2 & 22 \\
Bono East & 2.525 & 97.7 & 118 \\
Central & 4.492 & 95.8 & 181 \\
Eastern & 6.326 & 97.4 & 165 \\
Greater Accra & 67.490 & 97.8 & 2,610 \\
Northeast & 266 & 94.5 & 12 \\
Northern & 1.713 & 98.3 & 36 \\
Oti & 830 & 98.0 & 17 \\
Savannah & 229 & 85.2 & 26 \\
Upper East & 1.426 & 94.1 & 46 \\
Upper West & 690 & 86.4 & 78 \\
Volta & 4.933 & 97.1 & 176 \\
Western & 7.142 & 95.3 & 178 \\
Western North & 994 & 97.3 & 16 \\
International Travelers & 2.764 & 96.4 & 134 \\
\hline TOTAL & 125.565 & 98.5 & 4,295 \\
\hline \hline
\end{tabular}

TABLE VI: Percentage OF DeVice OWNership AND USERS In GHANA (SOURCE: GLOBAL Web INDEX, 2019)

\begin{tabular}{cc}
\hline \hline Device & Ownership Percentage \\
\hline \hline Mobile Phone (Any Type) & $81.0 \%$ \\
Smart Phone & $79.0 \%$ \\
Non-Smart Phone & $7.0 \%$ \\
Laptop/Desktop Computer & $43.0 \%$ \\
Tablet Device & $18.0 \%$ \\
Streaming Device & $2.3 \%$ \\
Game Console & $12.0 \%$ \\
Smart Home Device & $5.1 \%$ \\
Smart Watch/Wristband & $10.0 \%$ \\
Virtual Reality Device & $1.2 \%$ \\
\hline \hline
\end{tabular}

The dashboard dubbed "COVID-19 Operational Dashboard" had six panels (Fig. 4). The cases pane presented data on the cumulative case count; the active pane depicted current COVID-19 cases in each region; the map pane indicated the spatial distribution of the cases on a map with the help of the symbology; the trend pane also presented trend analyses of cases (cumulated, and active); whilst the percentage pane provided the percentage of cases per each region.

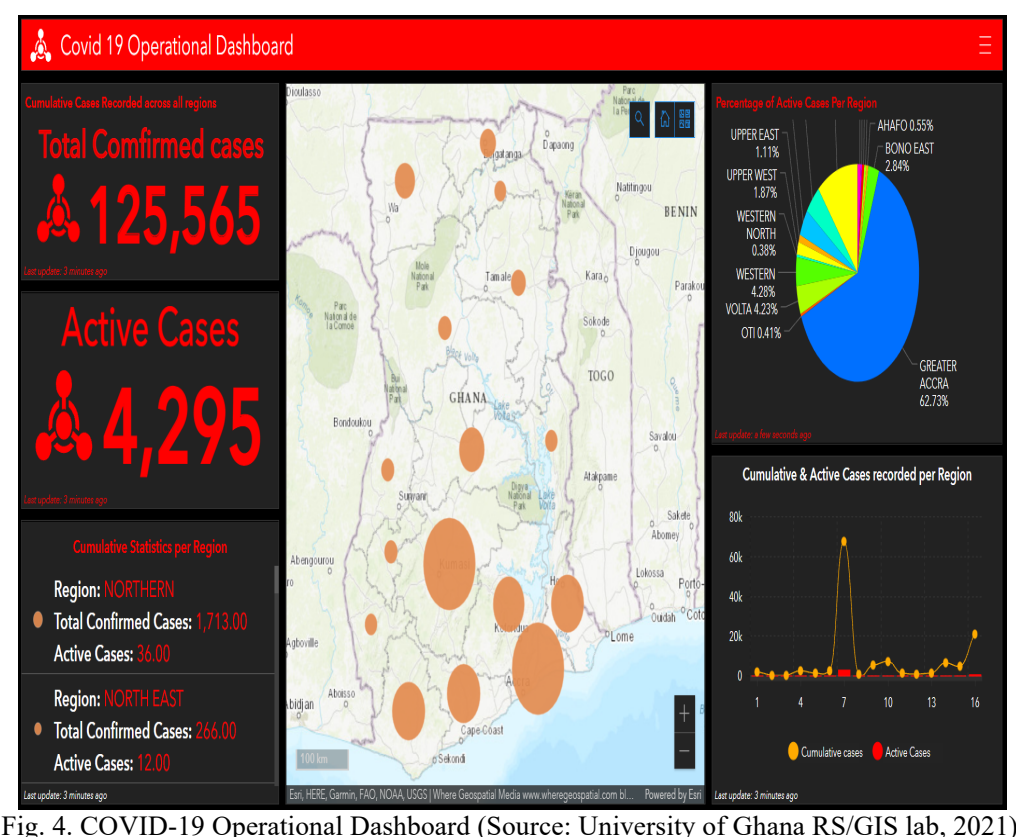

Fig. 5 presents COVID-19 hotspot map for Ghana. Based on the figure illustrated below, it can be observed that Greater Accra region has a high concentration of COVID-19 cases among the other regions in Ghana, followed by the Ashanti region. This may be due to the two regions, being highly populated. This, however, causes easy spread of the virus in such congested areas or regions. 


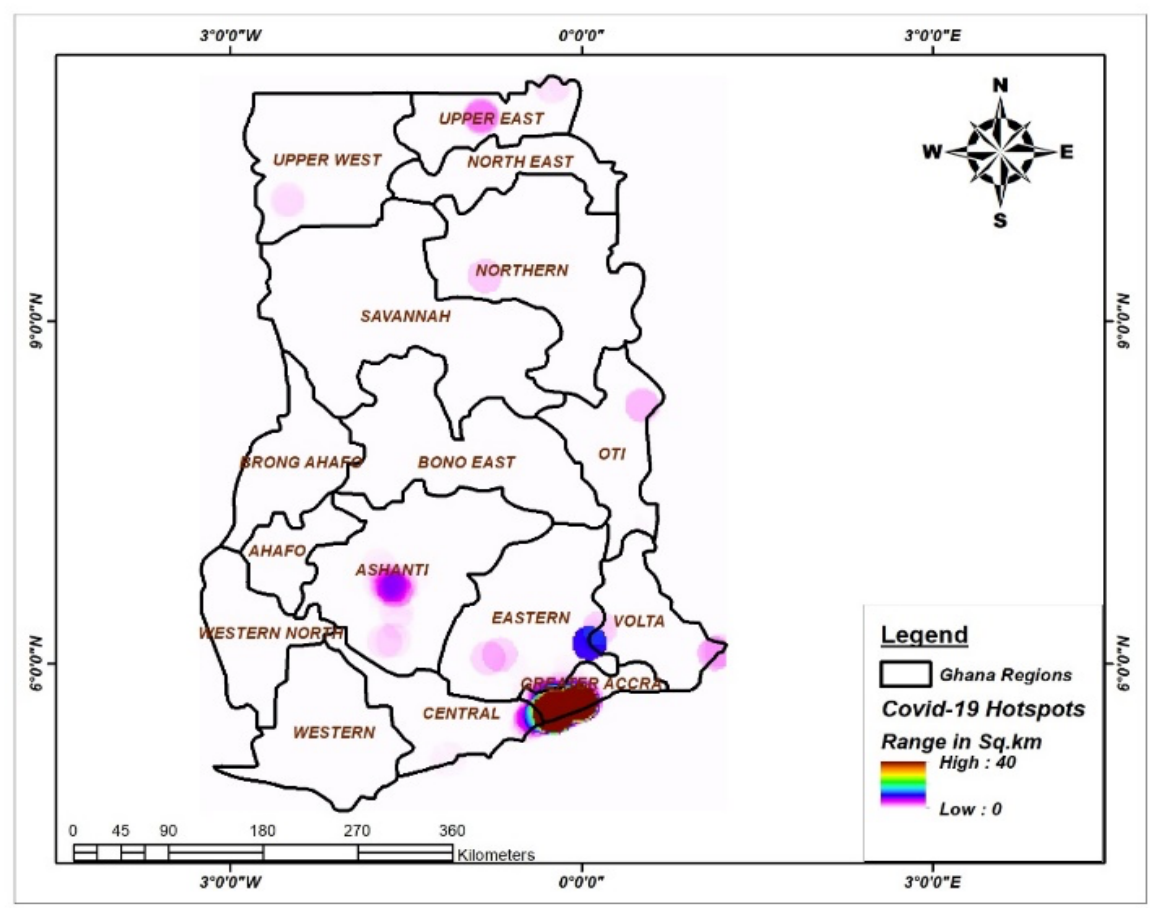

Fig. 5. COVID-19 Hotspots in Ghana.

Fig. 6 shows population size range for the various regions in Ghana based on the Ghana Statistical Service (GSS) (2021) Population and Housing Census (PHC) Provisional Results. The PHC results show that, the Greater Accra region (population size of $5,446,237$ ) has the highest population size in Ghana, followed by the Ashanti region (population size of 5,432,486). Here, population density in the two regions play key roles in the spread of the pandemic. Congestion in these regions based on reported cases presented in Fig. 4-5 makes it easy to draw conclusions that densely populated areas drive the spread of the virus from the host to another. This results in a lot of cumulative cases within the boundaries of these regions.

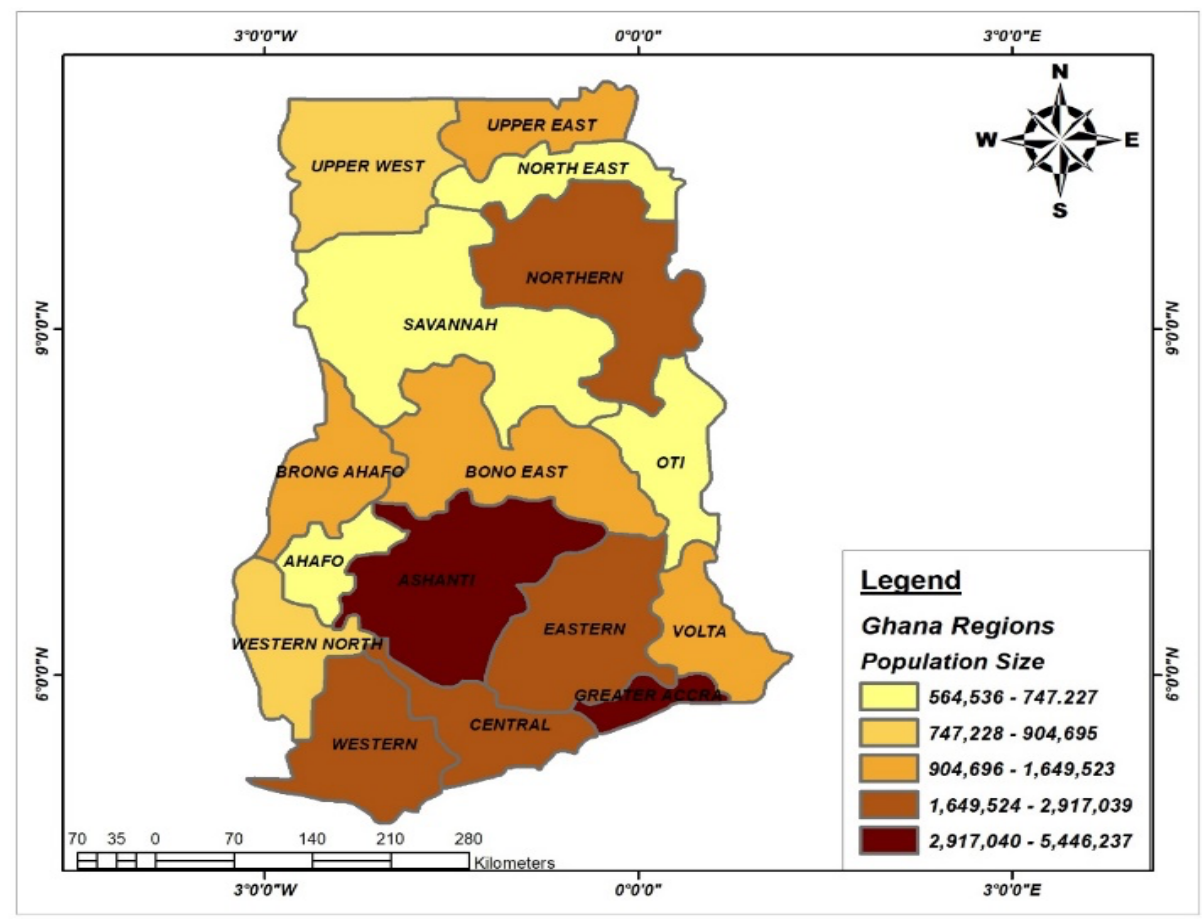

Fig. 6. Population size range per region in Ghana (Source: GSS, 2021).

Research conducted by Sarfo \& Karuppannan (2020) revealed that Johns Hopkins University's Center for Systems Science and Engineering developed an ArcGIS Online dashboard that displayed the spatial distribution of COVID-19 and its trend in China. The dashboard was accessed by over 160 million people, further depicting their interest in addressing the COVID-19 using the geospatial applications, including GIS, Remote Sensing, and drones. Findings from this research proves $90 \%$ of the respondents viewed the 
dashboard, indicating their interest in tracking and obtaining up-till-date information about the virus using GIS applications. Again, the findings from studies conducted by Kenu et al. (2020) and Sarfo \& Karuppannan (2020) corroborate with the findings of this research, which argued that the spatial pattern of COVID-19 cases in Ghana are highly concentrated in Accra, and Kumasi, respectively.

\section{Trend of Human Mobility during the COVID-19 Partial Lockdown in Ghana}

Fig. 7 gives an indication of how mobile phone data can provide quick and precise assessments of national and local human mobility behavior. It is valuable for monitoring and designing responses to public health emergencies such as the Coronavirus pandemic. Although the lockdown had not yet been implemented, many Ghanaians perhaps residents traveled home to their families in expectance of such protocols. Observations in Fig. 7 shows that there was about a 10-20\% decrease in mobility during the interval when initial restrictions were in place, compared to the baseline value. Relative to initial days, there was a slight increase, but marginal difference immediately after the announcement of lockdown measures.

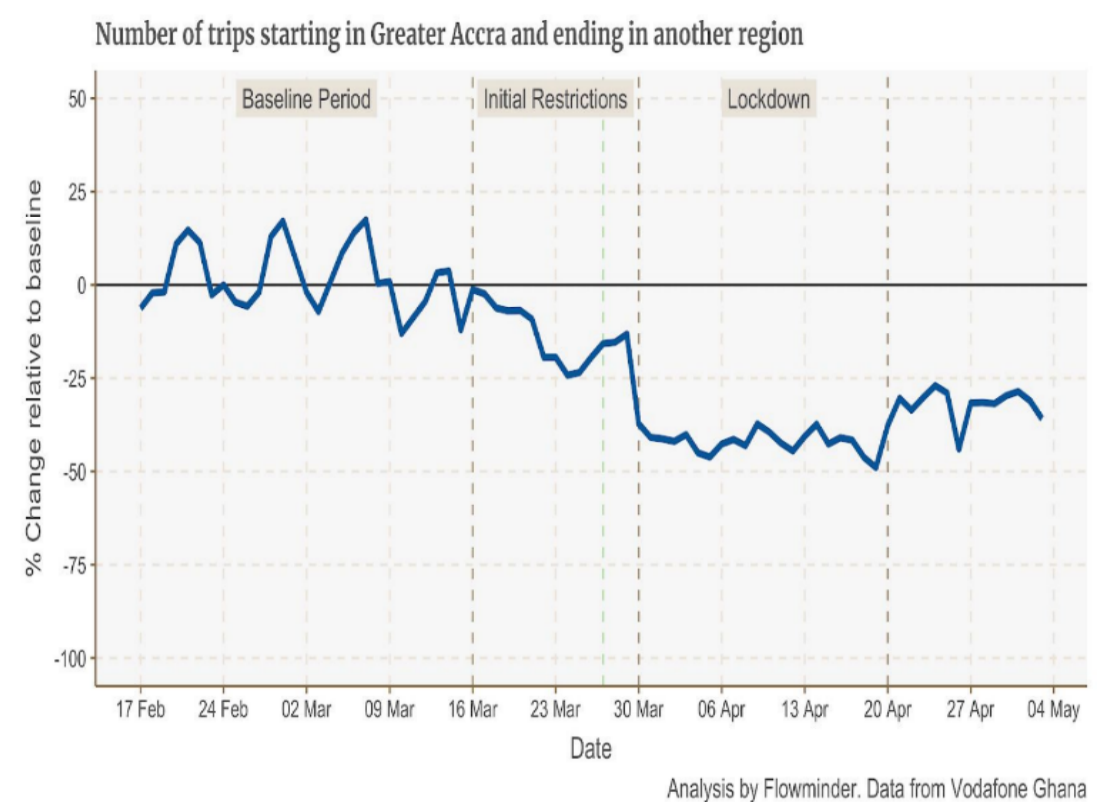

Fig. 7. Percentage change in the number of trips commencing in Greater Accra and ending in another region (Daily) (Source: Vodafone Ghana, 2021).

During the lockdown, however, mobility pattern reduced to $40 \%$, which was lower than the baseline rate. After the lockdown was lifted, mobility pattern immediately increased by roughly $15 \%$, similar to the lockdown period. Nevertheless, this was still below the normal rate, and the number of trips has continuously stayed $25-30 \%$ below the baseline value since the lockdown measures were lifted, albeit some of this decline could be ascribed to a drop in phone use compared to the baseline period.

\section{The Analytical Hierarchy Process (AHP)}

Analytic Hierarchy Process analysis was carried out to ascertain the pragmatism of study findings considering pairwise comparisons and weights calculated in relation to the elements stated and the role of geospatial technology in contact tracing.

TABLE VII: PAIRWISE MATRIX FOR THE CHALLENGES IDENTIFIED

\begin{tabular}{cccccc}
\hline \hline & PD & OA & AS & E/K & M \\
\hline \hline PD & 1 & 3 & 2 & 1 & 4 \\
OA & $1 / 3$ & 1 & 2 & 1 & 1 \\
$\mathrm{AS}$ & $1 / 2$ & $1 / 2$ & 1 & 1 & $1 / 2$ \\
$\mathrm{E} / \mathrm{K}$ & 1 & 1 & 1 & 1 & 1 \\
$\mathrm{M}$ & $1 / 4$ & 1 & 2 & 1 & 1 \\
$\mathrm{Sum}$ & 3.0833 & 6.5000 & 8.0000 & 5.0000 & 7.5000 \\
\hline \hline
\end{tabular}

TABLE VIII: CALCULATING CONSISTENCY FOR PARAMETERS LINKED TO THE CHALLENGES

\begin{tabular}{|c|c|c|c|c|c|c|c|c|c|c|c|c|}
\hline & PD & OA & AS & $\mathrm{Z}$ & $\mathrm{E} / \mathrm{K}$ & $\mathrm{M}$ & WSV & $\mathrm{CW}$ & "WSV/CW & $\lambda \max$ & $\mathrm{CI}$ & $\mathrm{CR}$ \\
\hline PD & 0.35 & 0.51 & 0.25 & & 0.19 & 0.66 & 1.96 & 0.35 & 25.53 & & & \\
\hline $\mathrm{OA}$ & 0.12 & 0.17 & 0.25 & & 0.19 & 0.16 & 0.89 & 0.17 & 5.27 & & & \\
\hline AS & 0.18 & 0.09 & 0.13 & & 0.19 & 0.0818 & 0.66 & 0.13 & 5.20 & 5.32 & 0.08 & 0.07 \\
\hline $\mathrm{E} / \mathrm{K}$ & 0.3538 & 0.1691 & 0.1262 & & 0.1873 & 0.1637 & 1.0000 & 0.1873 & 5.34 & & & \\
\hline $\mathrm{M}$ & 0.09 & 0.17 & 0.25 & & 0.19 & 0.16 & 0.86 & 0.16 & 5.26 & & & \\
\hline
\end{tabular}




\section{E. Interpretation}

The Consistency Ratio (CR) of the challenges on the pairwise matrix (Table 8) was 0.07. Further measurement of inconsistency (CR) was $\leq 0.10$ (the standard). The challenge aspects stated in the pairwise matrix was reasonably consistent, and the criteria weights can be employed for decision making (Table VII): In descending order of rank, Population Density (PD) was assigned 35.38 percent weight as the topranking element. Education/Knowledge (E/K) had 18.73\% weight; Overcrowded Areas (OA) obtained $16.91 \%$ weighting, Mobility (M) was assigned $16.37 \%$ weighting, whereas Age Structure (AS) was given a weighting of $12.62 \%$ (Table VIII).

TABLE IX: PAIRWISE MATRIX FOR THE IDENTIFIED PREVENTIVE MEASURES

\begin{tabular}{ccccccc}
\hline \hline & SP & V & BOPGC & CIA & MS & FCV \\
\hline \hline SP & 1 & 3 & 2 & 1 & 1 & 2 \\
V & $1 / 3$ & 1 & 2 & 2 & 1 & 2 \\
BOPGC & $1 / 2$ & $1 / 2$ & 1 & $1 / 2$ & 1 & 2 \\
CIA & 1 & $1 / 2$ & 2 & 1 & 2 & 3 \\
MS & 1 & 1 & 1 & $1 / 2$ & 1 & 2 \\
FCV & $1 / 2$ & $1 / 2$ & $1 / 2$ & $1 / 3$ & $1 / 2$ & 1 \\
Sum & 4.3333 & 6.5000 & 8.5000 & 5.3333 & 6.5000 & 12.0000 \\
\hline \hline
\end{tabular}

TABLE X: CALCUlating CONSISTENCY FOR THE PREVENTIVE MEASURES

\begin{tabular}{|c|c|c|c|c|c|c|c|c|c|c|c|c|}
\hline & SP & V & BOPGC & CIA & MS & FCV & WSV & $\mathrm{CW}$ & WSV/CW & $\begin{array}{c}\lambda \\
\max \\
\end{array}$ & CI & CR \\
\hline 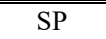 & 0.2 & 0.6 & 0.2 & 0.2 & $\overline{c 0.2}$ & $\overline{c 0.2}$ & 1.6 & 0.2 & 6.6 & & & \\
\hline $\mathrm{V}$ & 0.1 & 0.2 & 0.2 & 0.4 & 0.2 & 0.2 & 1.3 & 0.2 & 6.5 & & & \\
\hline BOPGC & 0.1 & 0.1 & 0.1 & 0.1 & 0.2 & 0.2 & 0.8 & 0.1 & 6.3 & 6.4 & 0.08 & 0.06 \\
\hline CIA & 0.2 & 0.1 & 0.2 & 0.2 & 0.3 & 0.2 & 1.3 & 0.2 & 6.2 & & & \\
\hline MS & 0.2 & 0.2 & 0.1 & 0.1 & 0.2 & 0.2 & 0.9 & 0.2 & 6.4 & & & \\
\hline FCV & 0.1 & 0.1 & 0.1 & 0.1 & 0.1 & 0.1 & 0.5 & 0.1 & 6.4 & & & \\
\hline
\end{tabular}

F. AHP Analysis of Preventive Measures of the Role of Geospatial Technology on Contact Tracing

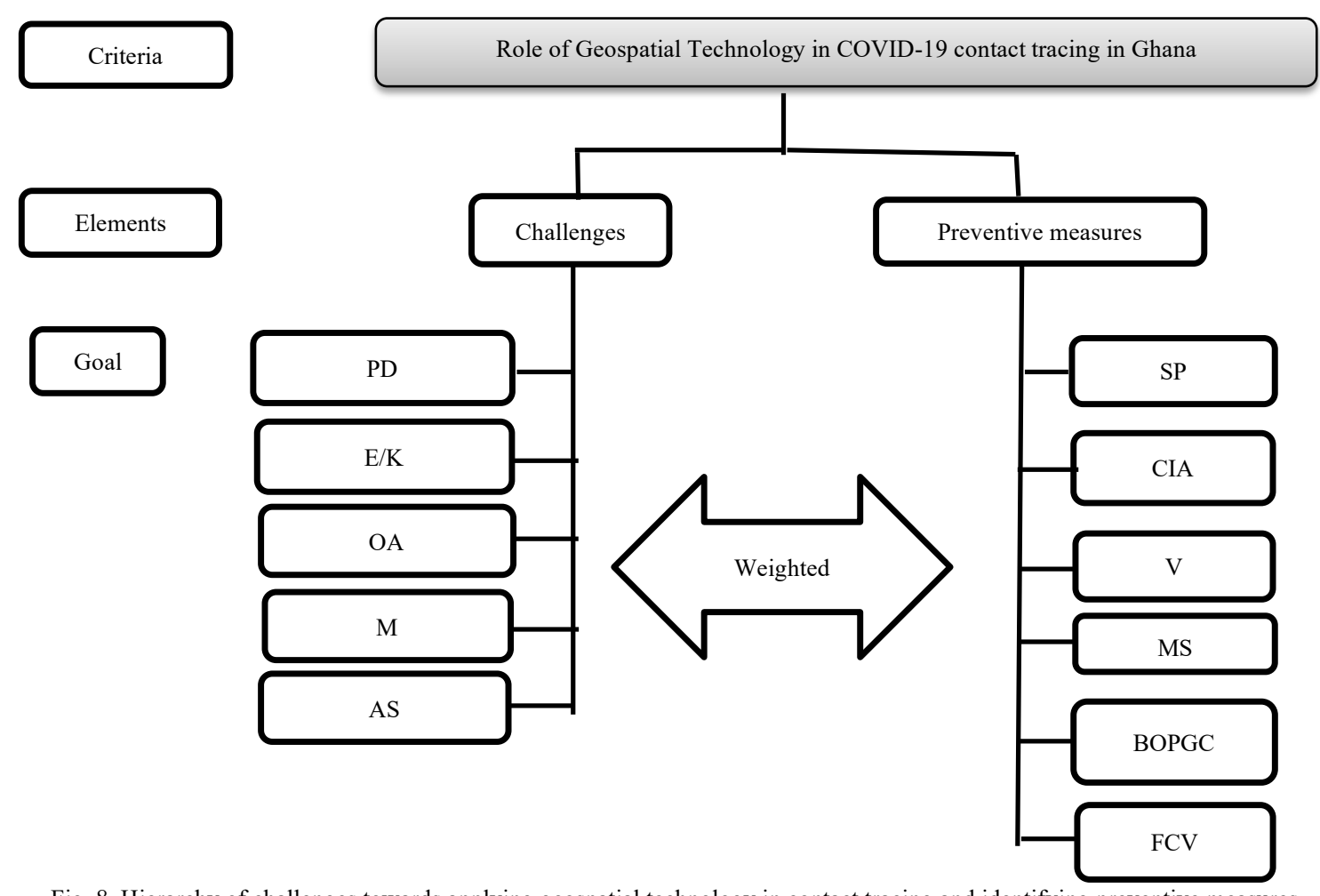

Fig. 8. Hierarchy of challenges towards applying geospatial technology in contact tracing and identifying preventive measures.

The Consistency Ratio (CR) of the preventive measures on the pairwise matrix was 0.06. Further measurement of inconsistency (CR) was less than or equal to 0.10 (the standard). In conclusion, elements for the preventive measures outlined in the pairwise matrix were consistent and can be used for decision making.

The weightings on the preventive measures as indicated in the pairwise matrix have been demonstrated in the (Tables IX and X). Elements were ranked as SP - Safety Protocol (23.93\%); CIA - Community and Individual Aid (21.47\%); V - Vaccine 19.36\%); MS - Media Sensitization (15.28\%); BOPGC - Ban on public gatherings and ceremonies (12.07\%) and FCV (7.90\%). Hierarchy of the elements on the pairwise 
matrix (Fig. 8) was designed based on criteria weights assigned to respondents' judgements to the parameters given. The pairwise matrices were normalized, and their respective consistency ratios were calculated accordingly.

\section{CONCLUSION}

The study sought to unravel the potential challenges of COVID-19 contact tracing in Ghana, coupled with the extent to which geospatial technology has been applied or could be applied to reduce some of the challenges. Findings of this study proved that geospatial technology can aid in addressing challenges to contact tracing implementation and management in Ghana. It further proved it is essential to prevent the transmission of COVID-19. The AHP tool was used to assign weight and ensure consistency in respondents' judgements considering subjectivity of qualitative tools like the use of research questionnaire, coupled with comparisons made based on the dashboard analysis (geospatial analysis) we carried out.

A huge number of cases were recorded in the southern part of the country, as against cases recorded in the northern zone. Mobility patterns depicted the migration of more people from regions with a high number of case count to regions with lower counts. Findings proved mobile device penetration in Ghana remains at about $81 \%$, and an overwhelming majority of young adults (79\%) who form greater part of Ghana's population use smart mobile phones as at January 2020. Currently, smart mobile phones and digital tools/mobile technologies used among the active population support GIS and GPS features. In this regard, it can be concluded that the application of geospatial technology in COVID-19 contact tracing in Ghana is feasible given that digital proximity tracking technology is adopted by 60 to $75 \%$ of the country's population to be maximally effective for contact identification. It is therefore recommended that appropriate infrastructures be put in place by the government, in order to integrate and adopt the application of geospatial technology in the public health system. Public health units among other key actors can employ this modernized technology to facilitate the achievement of location enablement and perform location analytics. This in essence, would amplify the odds of containing the spread of the virus, coupled with fighting against infectious disease outbreaks and epidemics.

\section{CONFLICT OF INTEREST}

Authors declare that they have no conflict of interest.

\section{ACKNOWLEDGEMENT}

We wish to thank the Almighty God for accomplishing this academic milestone. Again, we extend a special gratitude to the Editor and anonymous reviewers for their valuable comments and careful consideration that improved the overall nature of this manuscript.

\section{REFERENCES}

Afagbedzi, S. K., Owusu, A. B., Kissiedu, I. N., Amoako-Coleman, M., Bandoh, D. A., Noora, C. L. et al. (2021). Design and deployment of relational geodatabase on mobile GIS platform for real-time COVID-19 contact tracing in Ghana. Ghana Journal of Geography, 13(1), 126-146.

Agyapong, D., Asiamah, M., Andani, S.M. (2014). Financial Sustainability and Cost Recovery in Small Towns Water Systems in Eastern Region of Ghana. Athens Journal of Business \& Economics, 3(4), 383-404.

Chakraborty, A., \& Joshi, P. K. (2014). Mapping disaster vulnerability in India using analytical hierarchy process. Geomatics Natural Hazards and Risk, 20.

Danumah, J.H., Odai, S.N., Saley, B.M., Szarzynski, J., Thiel, M., Kwaky, A., et al. (2016). Flood risk assessment and mapping in Abidjan district using multi-criteria analysis (AHP) model and geoinformation techniques, (Cote d'Ivoire). Geoenviron Disasters, 3(1), 1-13.

Darko, G., Bi, S., Sarfo, I., Obiri, Y. A. S., Folorunso, E. A., Yeboah, E., et al. (2021). Impacts of climate hazards on coastal livelihoods in Ghana: the case of Ningo-Prampram in the Greater Accra region, Environ, Dev and Sustain, 1-30.

Elwood, S. \& Cope, M. (2009). Grounded visualization and scale: A recursive analysis of community spaces. Qualitative GIS: A Mixed Method Approach, 95-114.

Gao, Y., Yan, L., Huang, Y., Liu, F., Zhao, Y., Cao, L. et al. (2020). Structure of the RNA-dependent RNA polymerase from COVID19 virus. Science, 368 (6492): 779-782.

Ghana Health Service (GHS) (2021). COVID-19 situation update worldwide. https://www.ecdc.europa.eu/en/geographicaldistribution-2019-ncov-cases

Ghana Statistical Service (GSS) (2021, September 22). 2021 Population and Housing Census Press Release on Provisional Results (Unpublished). www.census2021.statsghana.gov.gh.

Global Web Index (2019). Global Web Index's Digital 2019 third Quarter Global Digital Statshot v01. https://www.slideshare.net/DataReportal/digital-2019-q3-global-digital-statshot-july-2019-v01.

Kenu, E., Frimpong, J., \& Koram, K. (2020). Responding to the COVID-19 pandemic in Ghana. Ghana Medical Journal, 54(2), $72-$ 73. 
Leung, J.T.Y. \& Shek, D.T.L. (2018). Family processes and adolescent achievement motivation in poor chinese single-mother families. Journal of Family Issues, 39(9), 2523-2544.

Muijs, D. (2010). Doing Quantitative Research in Education with SPSS 2nd Edition, London, GB. SAGE Publications (In Press). http://eprints.soton.ac.uk/id/eprint/165853.

Nejad, A. R. V., Esmaeili S., Aghamohammadi, H. (2015). Earthquake risk modeling using gis for urban buildings, case study: tehran municipality, district 3. Advances in Natural \& Applied Sciences, 9(1), 33-43.

Owusu, A. B., Afagbedzi, S. K., Bandoh, D. A., Frimpong, J. A., Kissiedu, I. N., Aikins, B. E., et al. (2021). Integration of multiple geospatial applications and intelligence for responding to COVID-19 in Ghana. Ghana Medical Journal, 55(2), 10-20.

Pourghasemi, H.R., Beheshtirad, M. and Pradhan. B. (2014). A comparative assessment of prediction capabilities of modified analytical hierarchy process (M-AHP) and Mamdani fuzzy logic models using Netcad-GIS for forest fire susceptibility mapping. Geomatics, Natural Hazards and Risk, 1-25.

Saaty, T. L. (1980). The Analytic Hierarchy Process: Planning, Priority setting, Resource allocation, Mc Graw-Hill, New York, 19.

Sapiezynski, P., Pruessing, J., \& Sekara, V. (2020). The Fallibility of Contact-Tracing Apps. Computers and Society, Cornell University. arXiv:2005.11297 [cs.CY].

Sarfo, A. K., \& Karuppannan, S. (2020). Application of geospatial technologies in the COVID-19 fight of Ghana. Transactions of the Indian National Academy of Engineering, 5(2), 193-204.

Shereen, M.A., Khan, S., Kazmi, A., Bashir, N., Siddique, R. (2020). COVID-19 infection: Emergence, transmission, and characteristics of human coronaviruses. Journal of Advanced Research, (24), 91-98.

Sibiri, H., Prah, D., Zankawah, S. M. (2020). Containing the impact of COVID-19: Review of Ghana's response approach. Health Policy and Technology, 10(1), 13.

Soroush, O., Sara, S., Steve, H., Liang, L. (2020). A person-to-person and person-to-place COVID-19 Contact Tracing System Based on OGC IndoorGML. Internation Journal of Geo-Information, 10 (1), 2.

Steinberg, S. J., \& Steinberg, S. L. (2006). Geographic information systems for the social sciences: investigating space and place, research methods, Sage.

Sun, J., Zhu, A., Li, H., Zheng, K., Zhuang, Z., Chen, Z. et al. (2020). Isolation of infectious SARS-CoV-2 from urine of a COVID19 Patient. Emerging Microbes \& Infections, 9(1), 991-993.

University of Ghana RSGIS Lab (2021). COVID-19 Operational Dashboard. https://ugarc.maps.arcgis.com/apps/dashboards/5995789cfa11436d9a897bebbedfcebb.

Vodafone Ghana (2021). Monitoring human mobility during the COVID-19 lockdown in Ghana using mobile phone data from Vodafone. https://www.migrationdataportal.org/data-innovation/human-mobility-COVID-19-Ghana-mobile-phone-data.

World Bank (2019). Countries and Economies: World Bank Population Statistics. https://data.worldbank.org/indicator/SP.POP.TOTL

World Health Organization (WHO) (2014). Case definition recommendations for Ebola or Marburg Virus Diseases. http://www.who.int/csr/resources/publications/ebola/ebola-case-definition-contact-en.pdf?ua=1.

World Health Organization (WHO) (2020). Coronavirus Disease (COVID-19): Weekly Epidemiological Update/Situational Report, https://iris.paho.org/handle/10665.2/53099.

Wu, F., Zhao, S., Yu, B., Chen, Y.M., Wang, W., Song, Z.G., et al. (2020). A new coronavirus associated with human respiratory disease in China. Nature, 579, 265-269.

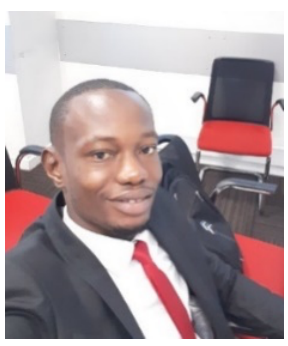

E. Yeboah is a master's student at the University of Ghana (UG), Legon pursuing Geoinformation Sciences. He holds a Bachelor's degree from the UG in Geography and Resource Development.

He currently works as a spatial analyst for Vodafone Ghana. His research focuses on GIS and Remote sensing technologies to collect, process, visualize and make statistical analysis using geospatial data. He is an expert in using computer software programs and tools such as ArcGIS, ENVI, google Earth, global positioning systems (GPS) and other Geographic Information Systems and Remote Sensing technologies for the aforementioned analysis. He has a number of publications to his name:

1. Yeboah, E., Sarfo, I., Nunoo, E. K., Kudoh, V., Shang, N., Addai, F. K., Amankwah, S. O. Y., \& Kedjanyi, E. A. G. (2021). GIS-Based Emergency Fire Response for Minimization of Fire Outbreaks in the Greater Accra Metropolis, Ghana. Journal of Geography, Environment and Earth Science International, 25(5), 30-45. https://doi.org/10.9734/jgeesi/2021/v25i530286.

2. Sarfo, I., Bi, S., Beibei, L. Amankwah, O. Y. S., Yeboah, E., Koku, J. E., Kwang, C. (2021). Spatiotemporal development of land use systems, influences and climate variability in Southwestern Ghana (1970-2020). Environ Dev Sustain (2021). Doi: 10.1007/s10668-021-01848-5.

3. Wakil Adamu, U., Yeboah, E., Sarfo, I., Kweku Nunoo, E., Kwang, C., Kofi Addai, F., Oduro, C., Darko, G., Ndafira, G. C., Batame, M., \& Aboagye Appea, E. (2021). Assessment of Oil Spillage Impact on Vegetation in South-Western Niger Delta, Nigeria. Journal of Geography, Environment and Earth Science International, 25(9), 31-45. https://doi.org/10.9734/jgeesi/2021/v25i930307.

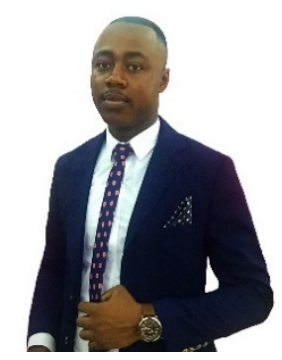

I. Sarfo is a doctoral student and graduate assistant in the Research Institute for History of Science \& Technology at Nanjing University of Information Science and Technology-China. He holds a Master's degree in Marine Ecosystem Management and Climate Change from Nha Trang University, Vietnam/University of Tromso, Norway.

His current research focuses on spatiotemporal development of land use systems, influences and climate variability in Ghana. He serves as an environmental consultant to a number of private institutions. He previously served as a teaching or research assistant in the Department of Environment and Development Studies at the Central University, Ghana. Mr. Sarfo is currently a member of the Organization of African Academic Doctors (OAAD). He has a number of publications in several SCI, Scopus and level A journals. Indicatively, the following:

1. Sarfo, I., Bi, S., Beibei, L. Amankwah, O. Y. S., Yeboah, E., Koku, J. E., Kwang, C. (2021). Spatiotemporal development of land use systems, influences and climate variability in Southwestern Ghana (1970-2020). Environ Dev Sustain (2021). Doi: 10.1007/s10668-021-01848-5.

2. Sarfo I; Bortey O.; Terney Kumara, T. (2019). Effectiveness of Adaptation Strategies among coastal communities in Ghana: The case of Dansoman in the Greater Accra region. Current Journal of Applied Science and Technology, 35 (6), 1-12. http://doi.org/10.9734/cjast/2019/v35i630211.

3. Sarfo, I., Yiadom, M. B., \& Dontoh, J. I. (2019). Concept of Climate Vulnerability: Key Determinants, Responses and Constraints to Climate Change Adaptation. Advances in Social Sciences Research Journal, 6(2) 232-253. http://dx.doi.org/10.14738/assrj.62.6109. 


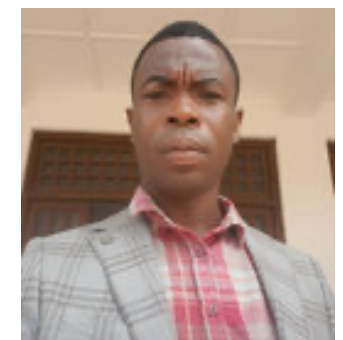

C. Kwang holds a doctoral and a Master's degree from Anadolu University, Space and Earth Science Institute, Eskisehir, Turkey and the University of Ghana, respectively. He is lecturer of Geographic Information Systems (GIS) and Remote Sensing at the Department of Geography and Resource Development of University of Ghana. His research areas include the application of GIS and Remote Sensing in environmental management, mineral exploration, as well as disease management and control. His publications include the following:

1. Sarfo, I., Shuoben, B., Beibei, L., Amankwah, S.O.Y., Yeboah, E., Koku, E.J., Kweku Nunoo, E., and Kwang, C. (2021). Spatiotemporal development of land use systems, influences and climate variability in Southwestern Ghana (1970-2020). Environ Dev Sustain. https://doi.org/10.1007/s10668-021-01848-5.

2. Wakil Adamu, U., Yeboah, E., Sarfo, I., Kweku Nunoo, E., Kwang, C., Kofi Addai, F., Oduro, C., Darko, G., Ndafira, G. C., Batame, M., \& Aboagye Appea, E. (2021). Assessment of Oil Spillage Impact on Vegetation in South-Western Niger Delta, Nigeria. Journal of Geography, Environment and Earth Science International, 25(9), 31-45. https://doi.org/10.9734/jgeesi/2021/v25i930307.

3. Kwang C., Adjei I. and Osei Jnr E.M (2018) The Contributions of Geographic Information Systems (GIS) to the Creditability and Transparency of the 2016 General Elections in Ghana. Global Journal of Human Social Science: F Political Science Volume XVIII Issue I Version I Year 2018, Online ISSN: 2249-460x \& Print ISSN: 0975-587

Dr. Kwang is a member of Ghana Geographers Association.

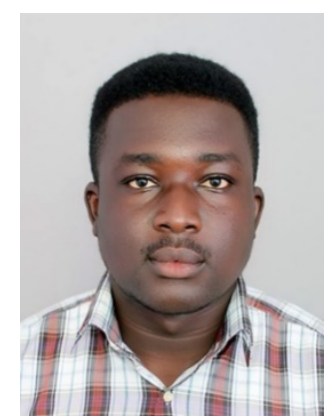

M. Batame is a Master's student within the faculty of Geo-Information Science and Earth Observation, University of Twente, The Netherlands. He graduated from the University of Ghana, Legon. He is a passionate researcher with research interests in the application of qualitative, quantitative, Geographic Information Systems, and Remote Sensing methods in natural resource management, climate change, urban planning management, and other spatial problems.

He worked at the Department of Geography and Resource Development, University of Ghana as a Teaching and Research Assistant. He has co-authored two papers:

1. Wakil Adamu, U., Yeboah, E., Sarfo, I., Kweku Nunoo, E., Kwang, C., Kofi Addai, F., Oduro, C., Darko, G., Ndafira, G. C., Batame, M., \& Aboagye Appea, E. (2021). Assessment of Oil Spillage Impact on Vegetation in South-Western Niger Delta, Nigeria. Journal of Geography, Environment and Earth Science International, 25(9), 31-45. https://doi.org/10.9734/jgeesi/2021/v25i930307.

2. Emerging adults' attitudes and perceptions towards ultra-processed foods, meat, fruit, and vegetable consumption in a university foodscape (Conference Paper).

In 2020, Mr. Batame received YouthMappers Community Outreach Award.

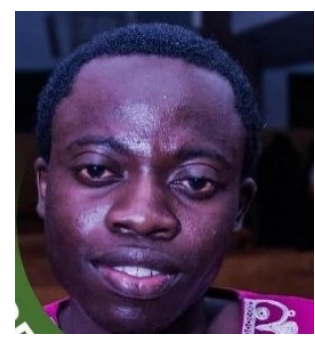

F. K. Addai is currently a final year master's student at the University of Ghana, Legon pursuing Geoinformation Sciences. His research interest dwells on using GIS and Remote Sensing to solve societal problems in the field of agriculture. Specifically, applying geospatial data to study soil and water processes and formations. He has an 8-year working experience in irrigation and mechanization. He possesses skills in soil assessments and hydrology. He has co-authored a number of publications which focuses on:

1. Wakil Adamu, U., Yeboah, E., Sarfo, I., Kweku Nunoo, E., Kwang, C., Kofi Addai, F., Oduro, C., Darko, G., Ndafira, G. C., Batame, M., \& Aboagye Appea, E. (2021). Assessment of Oil Spillage Impact on Vegetation in South-Western Niger Delta, Nigeria. Journal of Geography, Environment and Earth Science International, 25(9), 31-45. https://doi.org/10.9734/jgeesi/2021/v25i930307.

2. Yeboah, E., Sarfo, I., Nunoo, E. K., Kudoh, V., Shang, N., Addai, F. K., Amankwah, S. O. Y., \& Kedjanyi, E. A. G. (2021). GIS-Based Emergency Fire Response for Minimization of Fire Outbreaks in the Greater Accra Metropolis, Ghana. Journal of Geography, Environment and Earth Science International, 25(5), 30-45. https://doi.org/10.9734/jgeesi/2021/v25i530286.

3. Steiner, C., Bellwood-Howard, I., Häring, V. Tonkudor, K., Addai, F. et al. Participatory trials of on-farm biochar production and use in Tamale, Ghana. Agron. Sustain. Dev. 38, 12 (2018). https://doi.org/10.1007/s13593-017-0486-y.

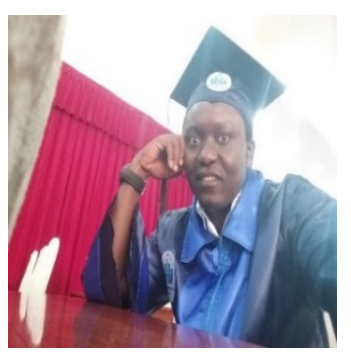

G. Darko holds a master's degree in Marine Ecosystem Management and Climate Change from Nha Trang University, Vietnam/University of Tromso, Norway. He currently serves as a research consultant for a number of institutions. He has particular interest in climate mitigation and adaptation, Multi-Criteria Decision-Making Analysis tools, among development related issues. He has authored and co-authored a number of publications in a number of SCI, Scopus and other highly esteemed journals:

1. Darko, G., Bi, S., Sarfo, I. et al. (2021). Impacts of climate hazards on coastal livelihoods in Ghana: the case of Ningo-Prampram in the Greater Accra region. Environ Dev Sustain(2021). https://doi.org/10.1007/s10668-021-01492-z.

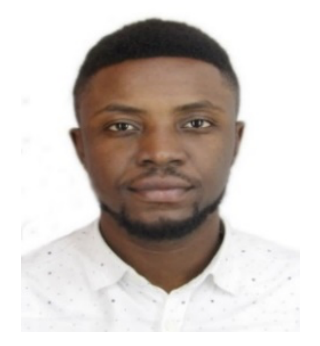

S. O. Y. Amankwah is currently pursuing a $\mathrm{PhD}$ degree in $3 \mathrm{~S}$ Integration and Meteorological Applications from the School of Geographical Sciences, Nanjing University of Information Science and Technology, Nanjing, China (NUIST). He holds a Master's degree in Environmental Science and Engineering from NUIST. He worked as a consultant for a number of non-governmental organizations. $\mathrm{He}$ has particular interest in remote sensing applications for disaster management using GIS and machine/deep learning techniques. 

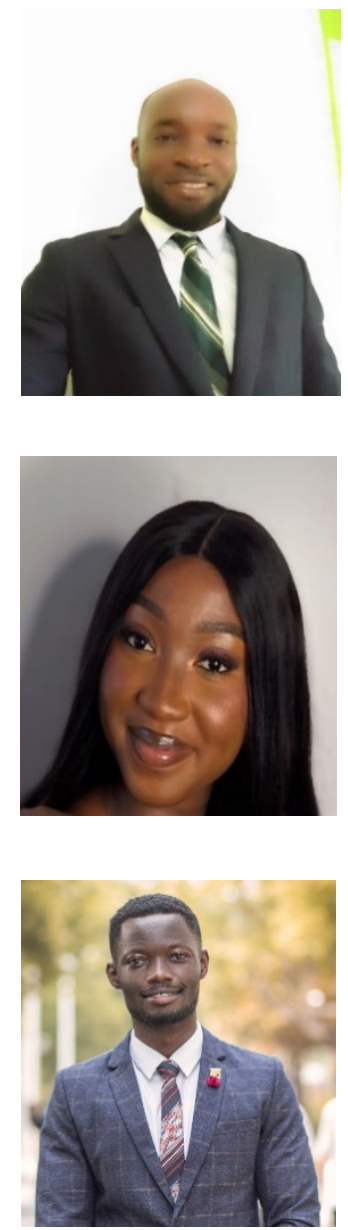

J. Nketiah holds a Master's degree in Geography \& Resource Development from the University of Ghana, Legon. He nurtures keen research interests in Geographic Information Systems and Natural Resource management. He has an 8-year working experience in the Local Government Service of Ghana as a Human Resource Manager currently stationed at the Keta Municipal Assembly in the Volta Region of Ghana.

E. A. Appea is a graduate from the University of Ghana with a Bachelor of Arts degree and a combined major in Economics and Geography. She hails from the Ashanti region of Ghana and nurtures keen interests in Data collection, Spatial analysis, map creation, data visualization of land use systems, climate variability, urban planning, environmental impact analysis and agricultural analysis. She is an executive Sales Assistant at Chocolate Clothes Global. A luxurious fashion brand in Ghana that designs Afrocentric clothing for men and women. She also worked at the Forestry Commission of Ghana as a national service personnel where she was mandated to serve under the Cartography Unit between September, 2020 and August, 2021. She served as a co-author for the publication:

1. Wakil Adamu, U., Yeboah, E., Sarfo, I., Kweku Nunoo, E., Kwang, C., Kofi Addai, F., Oduro, C., Darko, G., Ndafira, G. C., Batame, M., \& Aboagye Appea, E. (2021). Assessment of Oil Spillage Impact on Vegetation in South-Western Niger Delta, Nigeria. Journal of Geography, Environment and Earth Science International, 25(9), 31-45. https://doi.org/10.9734/jgeesi/2021/v25i930307.

C. Oduro is a doctoral student at the Research Institute for History of Science \& Technology at Nanjing University of Information Science and Technology-China who hails from the Ashanti region of Ghana. He holds a master's degree in Environmental Science and Engineering from the same university.

He previously served as a teaching or research assistant at the Kwame Nkrumah University of Science and Technology (KNUST), Kumasi-Ghana. His keen research interest focuses on global warming, climate change, and variability at regional and local levels using GIS and Climate Models. 